\title{
Research Paper: \\ Comparing the Performance Evaluation Models of Gas Refineries Using AHP and TOPSIS
}

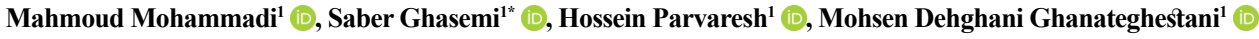 \\ 1. Department of Environment, Faculty of Natural Resources, Bandar Abbas Branch, Islamic Azad University, Bandar Abbas, Iran.
}

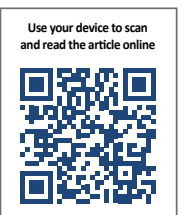

Cftation Mohammadi M, Ghasemi S, Parvaresh H, Dehghani Ghanateghestani M. Comparing the Performance Evaluation Models of Gas Refineries Using AHP and TOPSIS. Journal of Advances in Environmental Health Research. 2021; 9(4):333344. http://dx.doi.org/10.32598/JAEHR.9.4.1238

doi : http://dx.doi.org/10.32598/JAEHR.9.4.1238

\section{Keywords:}

Gas refinery, Environmental performance evaluation, Model, AHP, TOPSIS

\section{ABSTRACT}

Background: To basically solve the critical environmental problems, macro and infrastructural perspectives of rational development should be designed following environmental protection rules. Creating the proper performance measurement systems in every organization has had a promising interest in university studies, and many researchers are working on it.

Methods: This research intends to compare and rank 4 evaluation performance models used in gas refineries. To achieve the desired model in this study, we employed the grounded theory. The study research consisted of 20 professionals and Health, Safety, and Environmental (HSE) managers of gas refineries who had relevant experience and skills in this area. The normal score was estimated based on the weight obtained from the Analytic Hierarchy Process (AHP) to apply the Technique for Order Preference by Similarity to an Ideal Solution (TOPSIS) process and prioritize the models.

Results: The pairwise comparison matrix of 4 research models of the balanced scoring card, European foundation for quality management business excellence model, Iran national quality award, and environmental performance evaluation depicted that the geometric mean of the evaluation criteria includes the following items: the capability to quantify qualitative data for environmental performance, facilitating, efficient implementing, structuring, and mapping a roadmap of organization maturity to select an environmental performance estimated at 1.22 , $0.90,0.95$, and 0.96 , respectively. Also, the normal weights of these four criteria are estimated at $0.3039423,0.2242449,0.2347026$, and 0.2371102 , respectively.

Conclusion: The findings resulting from prioritizing the organization's Environmental Performance Evaluation (EPE) models based on TOPSIS depicted that the suggested model with relative proximity to $99 \%$ is the first choice of EPE for the gas refinery.

\footnotetext{
* Corresponding Author:

Saber Ghasemi, PhD.

Address: Department of Environment, Faculty of Natural Resources, Bandar Abbas Branch, Islamic Azad University, Bandar Abbas, Iran.

Phone: +98 (912) 0863546

E-mail: saberghasemi@gmail.com
} 


\section{Introduction}

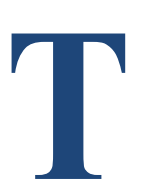

oday, the impact of the environment on the economic activities of human societies has raised the term of sustainable development in the world literature [1]. Because of the global trend of using quantitative information to reflect the state of the environment and its improvement, the measurement of sustainable development indices has increased, as well as control and accountability of managerial behaviors [2]. Sustainable development is the proper perception of the engagement to an interconnected system of economic, social, and environmental processes [3]. It is a popular belief that socioeconomic development is not acceptable without observing environmental issues [4]. Indeed, growing pollution, especially in industrial areas and its transfer to other parts, has created concern in the countries around the world and led to raising environmental protection at an international level [5].

Environmental protection refers to any operation done to preserve the environment or prevent its destruction [1]. To realize environmental protection, communities must take effective environmental decisions in this regard [6].

Many environmental problems challenge the control idea, but it is obvious that numerous organizations are looking for ways to recognize, realize, and promote their environmental performance [7]. This target can be obtained through optimally managing activities, products, and s e rvices with significant consequences [8]. Many industries are looking for ways to identify, realize, recognize, improve, and present their environmental performance better, and this endower becomes a reality when the factors affecting the environment are well known [9] and under efficient and effective management [10].

Environmental performance assessment is an internal management process and a tool to provide information and determine a reliable and acceptable status for the management to detect how an organization performs according to determined standards and legal requirements [11]. This management process enables the organization to assess its performance using key performance indicators and provide reliable and acceptable information for stakeholders [12].

Salehibarmi et al. [11], using the environmental perform ance model of Tehran Municipality, showed that the environmental management performance of Tehran Municipality in the field of preserving the urban environment and creating environmental centers in the neigh- borhoods is at a favorable and acceptable level. However, concerning biodiversity and green space of the city, wate $r$ and energy management, transportation, quality control, air pollution, and land and building use are not at the desired level. In a study, Najafzadeh and Mamipour [13] measured the environmental performance of regional power companies in Iran (in the context of the contemporaneous and consecutive boundary of the base surplus and directional distance function). The results show that Isfahan, Kerman, and Gilan regional power comp anies have the highest environmental efficiency, and Sistan-Baluchestan and Kish ones have the lowest. Hagh goo [14], in a study entitled "Evaluation of environmental performance and mechanisms affecting it according to ISO 14031", reported that organizations and industries should identify the factors affecting the environment and provide well-suited management to have a better environmental performance both internally and externally. Furthermore, Guijarro [15] presented a multicriteria model to evaluate environmental performance. In this research, a target programming pattern has been offered to rank countries in accordance with the multi-dimensional nature of environmental performance criteria considering 10 subject categories and 24 performance indicators.

Moreover, del Mar Alonso-Almeida and Fuentes-Frías [16] investigated 39 quality rewards and organizational excellence models worldwide. Then, they introduced 7 dimensions for evaluating and implementing Total Quality Management (TQM) in companies worldwide in cluster analysis. Talwar [17] also investigated 20 models of organizational excellence and the International Quality Award to identify the features and conflicts between these models to make suggestions and develop them.

The gas and petrochemical industries are among the mac ro and employment-creating industries. They are considered feed industries of other industries and play a $\mathrm{m}$ ain role in the progressive economic movement of countries [18]. Because of the growing trend of the global economy and rising energy demand, the key role of these industries has been increasingly considered and led to their significant expansion and development in recent decades [19]. While these industries face inevitable requirements to meet the environmental protection challenge, proper environmental management, which has become a success factor of these organizations, depends on their environmental performance assessment [20].

According to the growing evolution of business environ ments, fast-changing markets, and competitiveness promotion [21], the need for models that can assess the 
current status of organizations, recognize underlying causes and organizational damage, identify improvable areas, and create the proper basis for strategic planning, is more tangible than ever [9]. Also, because of the expansion of environmental considerations [22], many organizations are looking for new management techniques to realize, recognize, and improve their environmental performance [23]. In addition, the market for application software in this regard has grown a lot [24, 25]. But despite many models and contexts, some conceptual models of researchers have had the greatest impact on the formation of this particular field [26], including four models of the Balanced Scoring Card (BSC), European Foundation for Quality Management (EFQM) business excellence model, Iran National Quality Award (INQA) and Environmental Performance Evaluation (EPE).

Because of no uniform evaluation model for the environmental performance of refinery industries, this study aimed to compare different performance evaluation models and provide the most suitable model to assess the environmental performance of the country's gas refinery.

\section{Introducing Four Performance Evaluation Models}

The INQA model had been planned based on the latest edition of the EFQM, enabling organizations to develop processes and resources to promote product quality and create a transparent strategy for their products. It also empowers staff to implement the product strategy [9]. The eight core values and concepts of this model include consequentialism, customer orientation, leadership and consistency in goals, management based on processes and facts, human resource participation and develop-

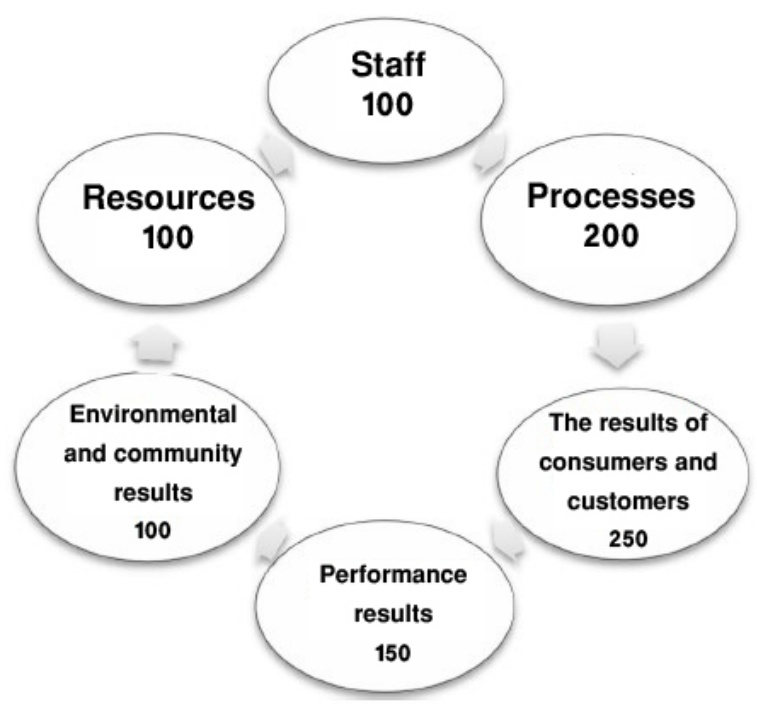

Figure 1. The block diagram of Iran National Quality Award (INQA) [27] ment, learning, innovation, continuous improvement, development of partnerships, and social responsibilities [27] (Figure 1).

The BSC is one of the most famous and well-known models of the performance evaluation system, created by Kaplan and Norton [28] and then extended and improved [26]. This model suggests that to assess the performance of any organization, a series of balanced indicators should be used so that top managers can have an overall view in terms of four important organizational aspects [29]. These different aspects make it possible to answer the following four basic questions:

1. What are the views on stakeholders? (Financial aspect)

2. What areas should be done well by us? (The internal aspect of the business)

\section{How do customers look at us? (Customer aspect)}

4. How can we continue to improve and create value? (learning and innovation aspects)

In a traditional performance measurement system, the emphasis was only on financial measurements, such as rate of return on investment or net income, but in the BSC performance measurement system, organizational performance is evaluated in terms of four prospects: financial, customers, internal processes, learning, and growth (Figure 2).

The EFQM was introduced at the beginning of 1992 as a context for evaluating and improving organizations for the European Quality Award and was revised in 1999 [30]. This model is now the most popular performance evaluation system in Europe [31]. The framework of this model includes two separate factors generally divided into "enablers" and "outcomes". The enablers are like levers that managers can use to achieve future results faster [30]. In particular, the main idea of this model is to improve organizational performance through self-assessment and improvable activities based on optimization in the field of nine excellence indicators [32] (Figure 3).

The EPE is an internal management process that uses indicators to compare an organization's environmental performance with its defined performance criteria (Figure 4). Based on ISO 14031 [33] and localized management and operational criteria, EPE reflects the two-dimensional position of the organization and can grow and 


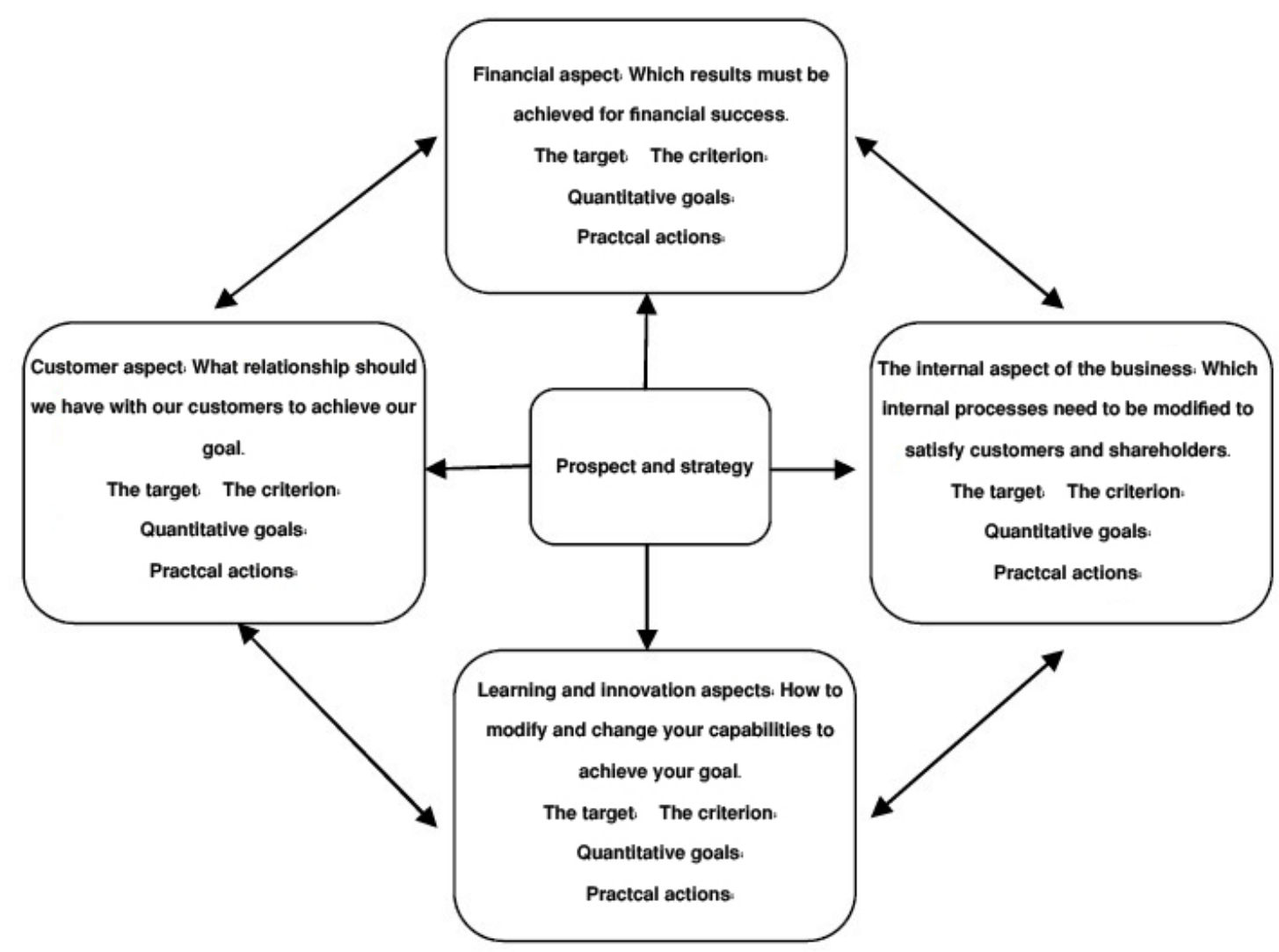

Figure 2. The block diagram of the Balanced Scoring Card (BSC) model [9]

develop it in a balanced way and can be used to compete with similar organizations.

\section{Materials and Methods}

\section{The study scope}

This study aims to present a model to evaluate the environmental performance of gas refineries (a case study is related to the ninth refinery of the South Pars Gas Complex).

South Pars Gas Complex (SPGC) is one of the subsidiaries of the National Iranian Gas Company, established in 2019, responsible for the operation of onshore facilities of multiple phases of the South Pars gas field. It is located in the territorial waters of Iran and Qatar and shared between two countries with an area of 9700 at a depth of 3000 below sea level. It is the largest gas field in the world, 105 from the coast of Asaluyeh Port. Its Iranian part covers an area of 3700 which reserves 14 trillion of gas and 17 billion barrels of gas condensate, equivalent to $8 \%$ of the world's gas reserves and $50 \%$ of the country's gas reserves. In terms of material resources, this field is considered the most important and valuable economic resource and the great and unique national wealth and treasure. The ninth refinery of the South Pars
Gas Complex, known as a leading company in Iranian projects, has been a model for other Iranian companies in recent years and is accountable for large and difficult national projects. This refinery is located in the Tombak region (15 east of Kangan and 65 east of Asaluyeh).

\section{Methodology}

The current study was conducted using a mixed exploratory research method.

First of all, according to the review of more than 500 studies in the field of performance evaluation and opinions of experts in this field, four performance evaluation models of BSC, EFQM, INQA, and EPE were selected as the most widely-used performance evaluation model.

In the following, by reviewing the literature on performance management and quality management, several criteria are selected to compare the excellence models. In this regard, experts, supervisors, and advisors were asked about these criteria and instructed to add or reject any criterion to the list. Finally, by gathering the opinions of experts, four main criteria agreed by the experts were extracted to evaluate and rank the models of organizational excellence as follows: 


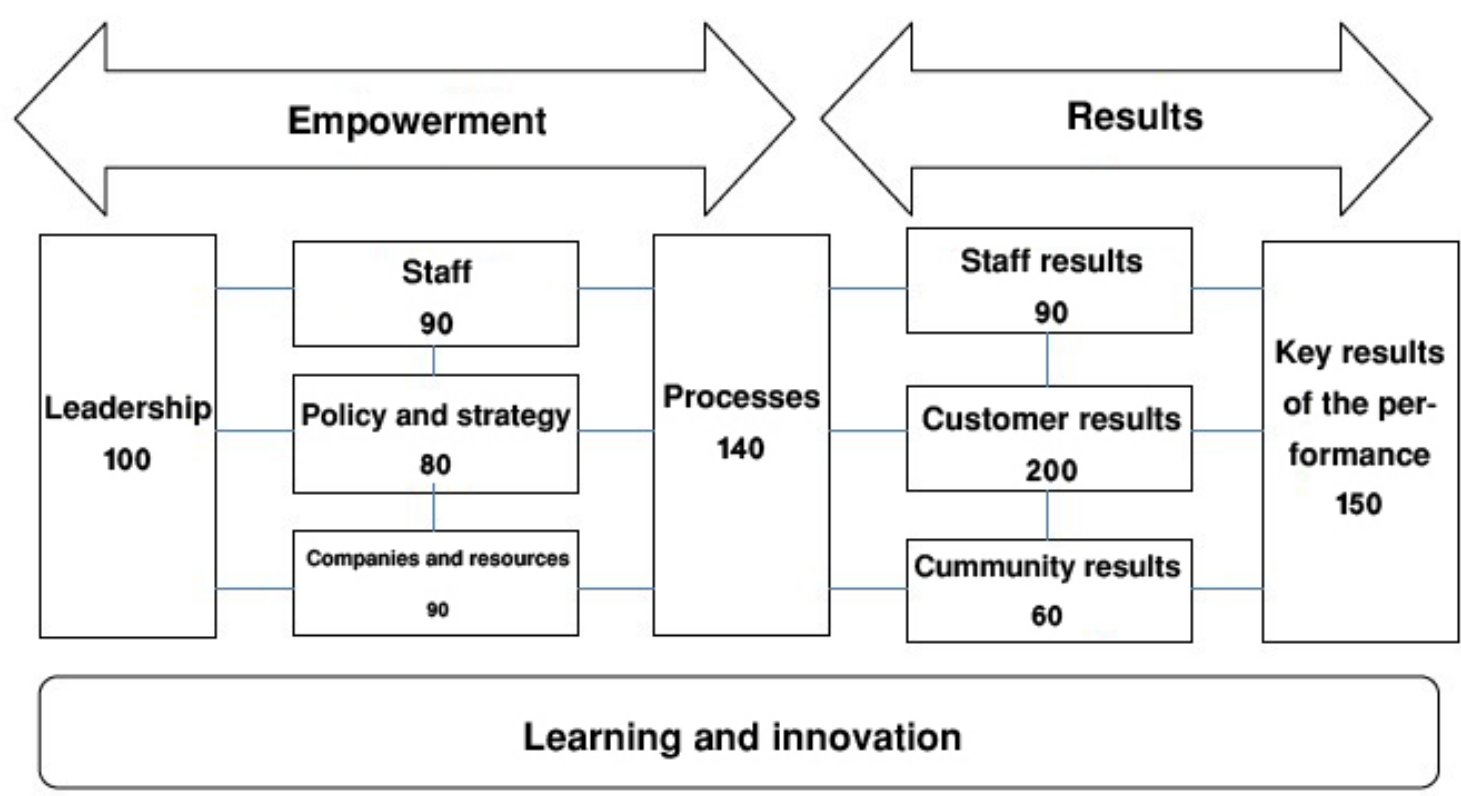

Figure 3. The Block Diagram of European Foundation for Quality Management (EFQM) [32]

Criterion 1: Capability to quantify qualitative data for environmental performance

Criterion 2: Facilitating and efficient implementing

\section{Criterion 3: Structuring}

Criterion 4: Mapping a roadmap of organization maturity to select an environmental performance

Finally, using the fuzzy Analytic Hierarchy Process (AHP) and the Technique for Order Preference by Similarity to an Ideal Solution (TOPSIS), pairwise comparisons were identified in the target population after distributing the questionnaire.
The validity of the questionnaire was determined through content validity and its reliability through the Cronbach alpha coefficient $(\alpha=0.94)$.

Figure 5 shows the implementation steps of the research process to determine the best model to evaluate the environmental performance of gas refineries. Figure 6 also presents a research model based on a hierarchical structure to prioritize research models.

\section{The statistical community of research}

The study population of this research included managers and experts working in different parts of gas refineries with at least 5 years of relevant work experience in HSE (health, safety, and environmental) and manage-

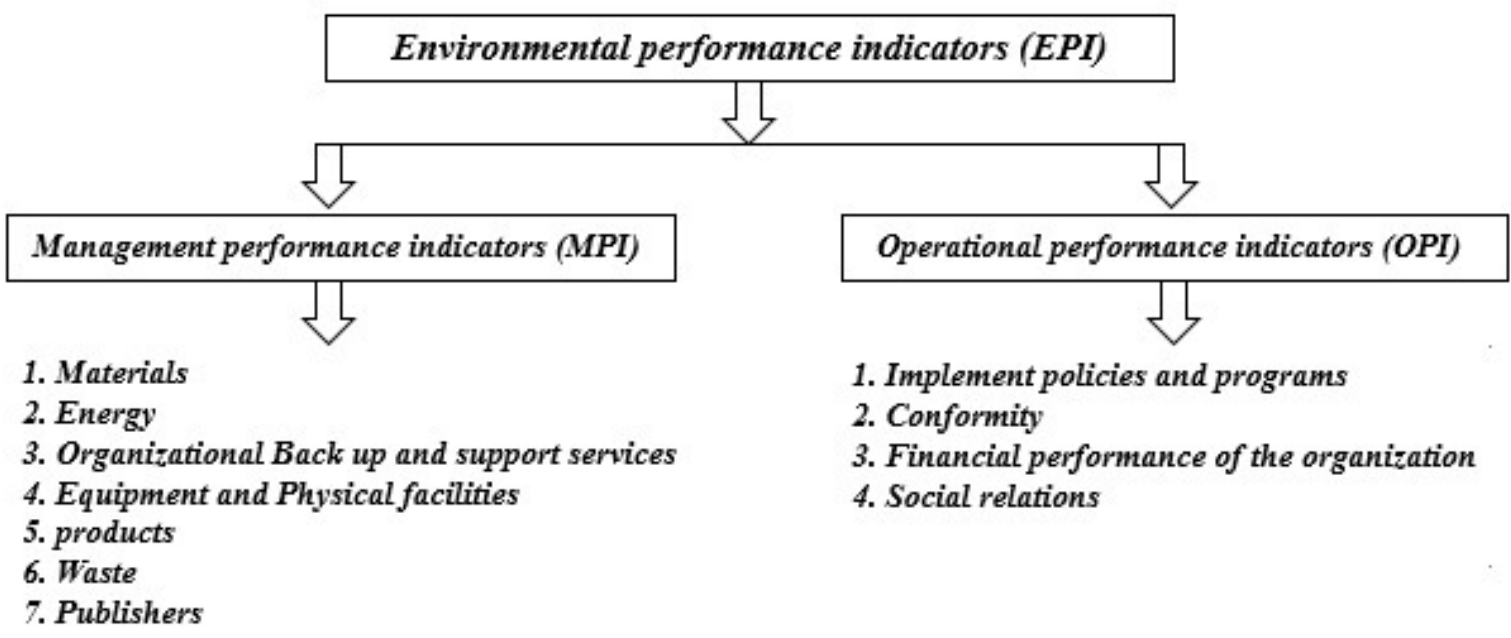

Figure 4. The block diagram of the Environmental Performance Evaluation (EPE) [34] 


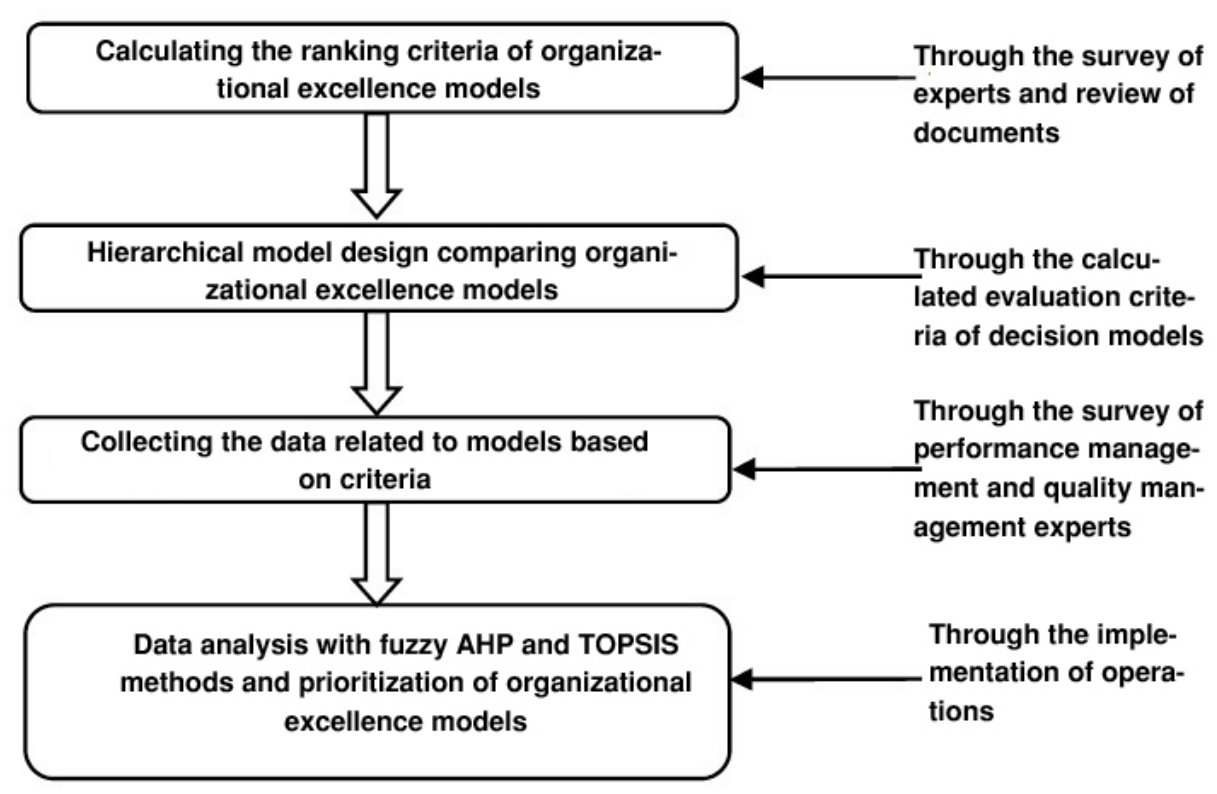

Figure 5. Implementation steps of the research process to determine the best model to evaluate the environmental performance of gas refineries

ment. The maximum sample was randomly determined 20 people based on the Cochran formula for multicriteria decision-making. The research data were collected by questionnaire based on environmental performance evaluation indicators (research options). Considering the existence of 22 professionals and HSE managers and officials in the SPGC who had experience and skills and taking into account the 5\% error level, the study sample of 20 people was selected (Table 1). They are chosen by the snowball method.

The experts agreed upon 4 main criteria of the capability to quantify quality data for environmental performance, facilitating, efficient implementing, structuring, and mapping a roadmap of organization maturity to select an environmental performance.

\section{Data analysis method}

In this study, the collected data should be analyzed and turned into information that describes the environmental performance of the organization (gas refineries). In other words, they are expressed as an evaluation of environmental performance. To avoid prejudging in achieving the results, all reliable and relevant data already collected were also considered.

The accuracy, adequacy, and completeness of the data are also considered in the data analysis. Finally, fuzzy AHP and TOPSIS were utilized to measure the sub-criteria and extracted indicators.

\section{Fuzzy TOPSIS}

The fuzzy TOPSIS technique is a generalization based on the TOPSIS technique in a fuzzy environment. Hwang and Yoon introduced the TOPSIS technique in 1981.

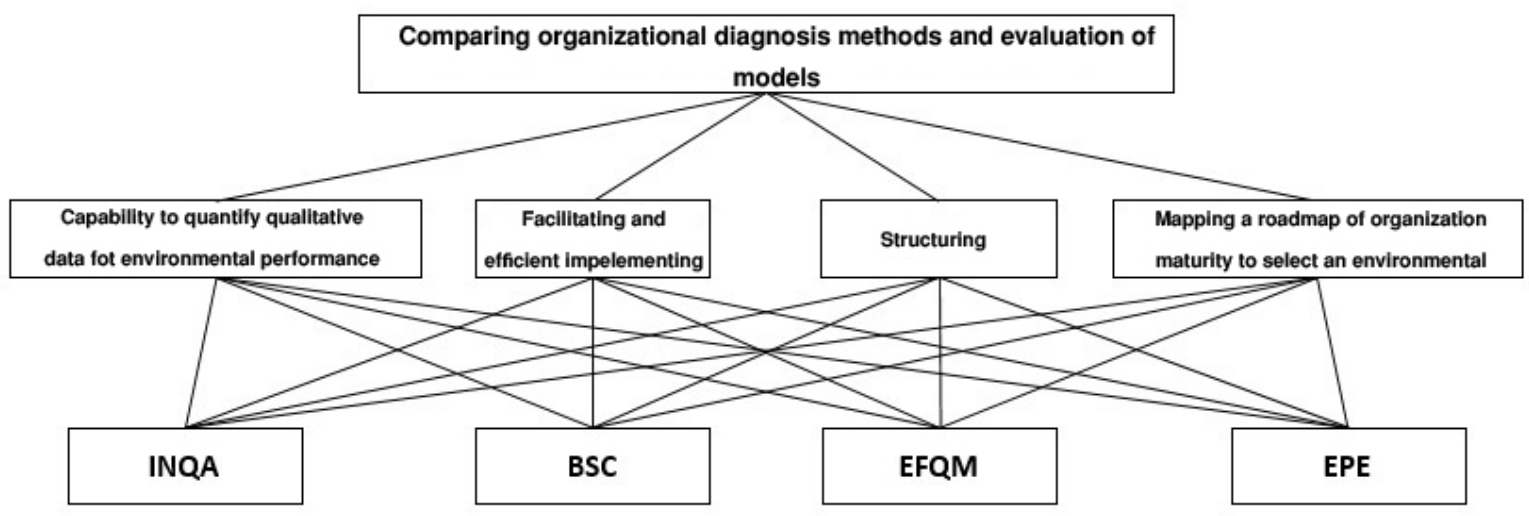

Figure 6. Research model based on hierarchical structure to prioritize research models 
Table 1. Characteristics of experts in the research sample

\begin{tabular}{|c|c|c|c|}
\hline Expertise & Degree of Education & No. & Description \\
\hline HSE management & Master and higher & 4 & Inside of the organization (SPGC) \\
\hline Operations management & Master & 2 & Inside of the organization (SPGC) \\
\hline Refining engineering & Master & 2 & Inside of the organization (SPGC) \\
\hline Technical inspection & Master & 2 & Inside of the organization (SPGC) \\
\hline Repairs & Bachelor and Master & 3 & Inside of the organization (SPGC) \\
\hline Financial management & Master & 1 & Inside of the organization (SPGC) \\
\hline Real estate and green space & Master & 1 & Inside of the organization (SPGC) \\
\hline Operation & Master & 2 & Inside of the organization (SPGC) \\
\hline Environmental management & Master and PhD. & 3 & $\begin{array}{l}\text { Outside of the organization (provincial directorate of envi- } \\
\text { ronment and city directorate of the environment) }\end{array}$ \\
\hline
\end{tabular}

SPGC: South Pars Gas Complex; HSE: Health, Safety, and Environmental.

TOPSIS underlying logic is the definition of positive and negative ideal solutions. A positive ideal solution maximizes profit criteria and minimizes cost criteria. The ideal negative solution maximizes cost criteria and minimizes profit criteria. The optimal option is the closest option to the positive ideal solution and the farthest option from the negative ideal solution. In short, the positive ideal solution is a combination of the best achievable values of the criteria, while the negative ideal solution contains the worst achievable values of the criteria.

\section{AHP technique}

In decision-making science, in which the selection of a strategy among the existing strategies or the prioritization of strategies is discussed, recently Multicriteria Decision-Making (MCDM) methods have been introduced. In such decisions, several indicators or targets that are sometimes contradictory are considered. If the MCDM refers to the attribute indicator criteria, it is known as a MADM (multi-attribute decision-making). If the MCDM refers to the objective indicator criteria, it is called Multi-Objective Decision-Making (MODM). One of the first decision-making methods with MADM indicators is the AHP method, which has been utilized more than other methods in management science.

\section{Results and Discussion}

The growing expansion of industries and scientific advances has created new horizons of environmental impacts, and different outcomes of health and safety categories are detected each year [34]. As mentioned before, projects of upstream petrochemical industries in the country showed that in previous programs, natural and environmental values had been overlooked [35]. The result of such measures has been the occurrence of various pollutions and severe destruction of environmental resources [19]. So, large industries such as refineries are increasingly moving towards integrated HSE

Table 2. Pairwise comparison matrix of criteria of four research models

\begin{tabular}{ccccccc}
\hline Comparison Criterion & Criterion 1 & Criterion 2 & Criterion 3 & Criterion 4 & Geometric Mean & Normal Weight \\
\hline Criterion 1 & 1.00 & 3.00 & 0.25 & 3.00 & 1.22 & 0.3039423 \\
Criterion 2 & 0.33 & 1.00 & 1.00 & 2.00 & 0.90 & 0.2242449 \\
Criterion 3 & 4.00 & 1.00 & 1.00 & 0.20 & 0.95 & 0.2347026 \\
Criterion 4 & 0.33 & 0.50 & 5.00 & 1.00 & 0.96 & 0.2371102 \\
\hline
\end{tabular}

Criterion 1: The capability to quantify qualitative data for environmental performance; Criterion 2: Facilitating, efficient implementing; Criterion 3: Structuring; and Criterion 4: Mapping a roadmap of organization maturity to select an environmental performance. 


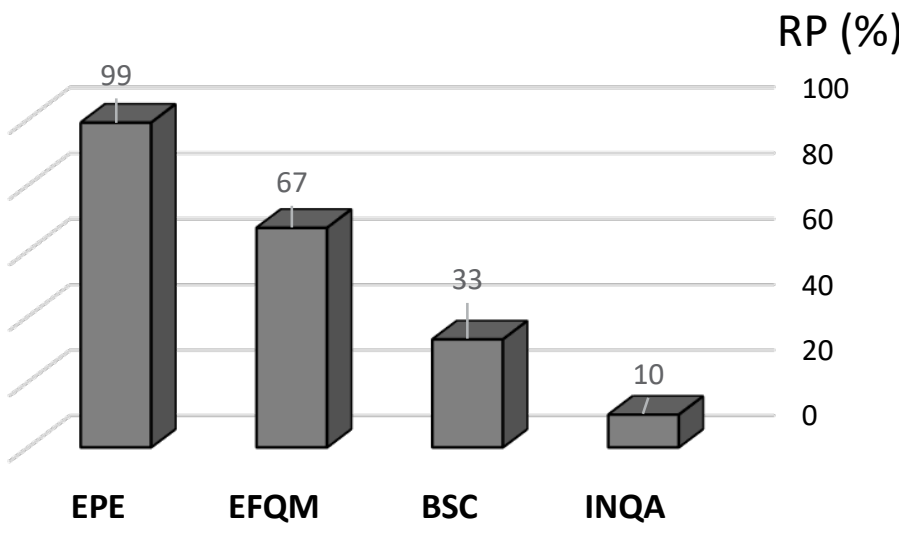

Figure 7. Ranking the EPE models according to the degree of proximity to the positive ideal solution and distance from the negative ideal solution in the TOPSIS method

management systems and trying to achieve the goals of the vision documents of these systems [22]. These organizations always encounter the inevitable requirements to meet the challenge of environmental protection, and proper environmental management has become a factor in the success of these organizations [36].

Proper environmental management of an organization depends on the EPE of the organization to realize and improve the managing elements of the organization's activities, products, and services that interact with the environment
[37]. However, ISO 14031 provides instruction for assessing and monitoring the ecological performance of an organization [23]. Unfortunately, measuring these indicators has remained one of the biggest challenges and problems of organizations, especially competent institutions [23]. Several models have been proposed to evaluate environmental performance in Iran $[37,38]$. In this research, according to the experts, four models of INQA, BSC, EFQM, and EPE were evaluated. The analyses results were identified by a conceptual model of the research using the fuzzy AHP method

Table 3. The index score of four criteria to evaluate research models

\begin{tabular}{ccccc}
\hline Evaluation Models & Criterion 1 & Criterion 2 & Criterion 3 & Criterion 4 \\
\hline INQA & 5 & 7 & 7 & 6 \\
BSC & 6 & 6 & 8 & 6 \\
EFQM & 7 & 6 & 8 & 8 \\
EPE & 8 & 7 & 6 & 8 \\
\hline
\end{tabular}

INQA: Iran national quality award; BSC: Balanced Scoring Card; EFQM: European foundation for quality management; EPE: Environmental performance evaluation.

Table 4. The normal score of criteria for each evaluation model based on the weight obtained from AHP

\begin{tabular}{ccccc}
\hline Evaluation Models & Criteria 1 & Criteria 2 & Criteria 3 & Criteria 4 \\
\hline INQA & 0.303942 & 0.224245 & 0.234703 & 0.23711 \\
\hline BSC & 1.519712 & 1.569714 & 1.642918 & 1.422661 \\
\hline EFQM & 1.823654 & 1.345469 & 1.877621 & 1.422661 \\
\hline EPE & 2.127596 & 1.345469 & 1.877621 & 1.896882 \\
\hline
\end{tabular}

INQA: Iran national quality award; BSC: Balanced Scoring Card; EFQM: European foundation for quality management; EPE: Environmental performance evaluation. 
Table 5. The prioritization of an organization's EPE models based on TOPSIS

\begin{tabular}{|c|c|c|c|c|c|}
\hline \multicolumn{2}{|c|}{ Performance evaluation models } & \multirow{2}{*}{$\begin{array}{l}\text { Criteria } 1 \\
0.379049\end{array}$} & \multirow{2}{*}{$\begin{array}{c}\text { Criteria } 2 \\
0.536875\end{array}$} & \multirow{2}{*}{$\begin{array}{c}\text { Criteria } 3 \\
0.479632\end{array}$} & \multirow{2}{*}{$\begin{array}{c}\text { Criteria } \\
0.424264\end{array}$} \\
\hline \multirow{4}{*}{$\begin{array}{l}\text { Calculation of the } \\
\text { Score Index }\end{array}$} & INQA & & & & \\
\hline & BSC & 0.454859 & 0.460179 & 0.548151 & 0.424264 \\
\hline & EFQM & 0.530669 & 0.460179 & 0.548151 & 0.565685 \\
\hline & EPE & 0.606478 & 0.536875 & 0.411113 & 0.565685 \\
\hline \multirow{7}{*}{$\begin{array}{l}\text { Index weights using } \\
\text { Shannon's entropy }\end{array}$} & INQA & 0.192308 & 0.269231 & 0.241379 & 0.214286 \\
\hline & BSC & 0.230769 & 0.230769 & 0.275862 & 0.214286 \\
\hline & EFQM & 0.269231 & 0.230769 & 0.275862 & 0.285714 \\
\hline & EPE & 0.307692 & 0.269231 & 0.206897 & 0.285714 \\
\hline & $\mathrm{E}$ & 0.989241 & 0.997864 & 0.995176 & 0.992614 \\
\hline & D & 0.010759 & 0.002136 & 0.004824 & 0.007386 \\
\hline & W & 0.428551 & 0.00274 & 0.006188 & 0.009474 \\
\hline \multirow{6}{*}{$\begin{array}{c}\text { Balanced } \\
\text { non-scale matrix }\end{array}$} & INQA & 0.082414 & 0.000738 & 0.001494 & 0.00203 \\
\hline & BSC & 0.098896 & 0.000632 & 0.001707 & 0.00203 \\
\hline & EFQM & 0.115379 & 0.000632 & 0.001707 & 0.002707 \\
\hline & EPE & 0.131862 & 0.000738 & 0.00128 & 0.002707 \\
\hline & MAX & 0.131862 & 0.000738 & 0.001707 & 0.002707 \\
\hline & MIN & 0.082414 & 0.000632 & 0.00128 & 0.00203 \\
\hline
\end{tabular}

INQA: Iran national quality award; BSC: Balanced scoring card; EFQM: European foundation for quality management; EPE: Environmental performance evaluation, E: entropy values of each criteria, D: degree of the intrinsic information of each criteria, W: weights of each criteria.

after distributing the pairwise comparison questionnaire to the target population.

The pairwise comparison matrix of the criteria of four research models depicted that the geometric mean of the evaluation criteria of the capability to quantify quality data for environmental performance, facilitating, efficient implementing, structuring, as well as mapping a roadmap of organization maturity to select an environmental performance was estimated as $1.22,0.90,0.95$, 0.95 , and 0.96 , respectively. Normal weights of these four criteria are $0.3039423,0.2242449,0.2347026$, and 0.2371102 , respectively (Table 2 ).

Elite scores for each model were estimated based on the above comparison criteria, from the lowest number 1 to the highest number 9 (Table 3), and the normal score based on the weight obtained from AHP to apply the TOPSIS process, and prioritize the models (Table 4). The current results of prioritizing the organization's EPE models based on TOPSIS (Table 5) showed that the proposed model of the EPE with the relative proximity of $99 \%$ is the priority of the EPE for gas refineries (Figure 7).

Abbreviations: INQA, Iran national quality award; BSC, balanced scoring card; EFQM, European foundation for quality management; EPE, environmental performance evaluation.

The results depicted that the proposed model of the EPE with the relative proximity of $99 \%$ is the first choice for the gas refinery evaluation. 
A comprehensive performance evaluation system is a necessity for public and private organizations. Of course, the intensity of performance evaluation models makes it difficult for organizations to select the optimal model. Many models have been and are helpful to evaluate the performance in different situations [9]. The current study showed that the EPE model is more suitable to assess the performance of gas refineries than other models. In the field of the application of performance evaluation models, there are many studies in which one or at most two models have been utilized independently or in combination in the organization and presented the model implementation results. For instance, because of the growing awareness of intellectual property rights in European research institutes and the sensitivity of this issue, Smandek et al. [39] used the BSC model to overcome the conflict of expectations in this area. Maria del Mar Alonso-Almeida and Fuentes-Frías [16] reported that researchers in many countries believe that the international quality awards and quality excellence models are the appropriate formats for growth and promotion to achieve excellence criteria in the fields of TQM. In contrast, Azar et al. [9] have considered the scoring card model and the organization excellence model as the best models. Williams et al. [40] also reported that most of the businesses are trying to improve the performance of their organization through the use of excellence models, such as the European Foundation's Quality Excellence Model. The authors note that most of these organizations have recently expressed dissatisfaction with using these models.

Although in this investigation, the defaults and philosophy of models are part of the comparative criteria, the main goal is to compare the models and select the optimal model to conduct research, not just deal with one or more models. Indeed, according to the research method, which is a hierarchical analysis process, the models are not measured independently based on the criteria but are confronted with each other. The score of models makes sense with pairwise comparisons of the criteria [41].

\section{Conclusion}

The studies show that the environmental issues affecting all gas refineries require managers to formulate strategies to conserve natural resources and curb environmental pollution. The EPE provides good ideas to establish the basis for remedial actions in the areas where the performance has not improved significantly or even declined. Unfortunately, in domestic organizations and companies, there is inadequate data on the environmental dimensions of various production, design, development, and after-sales service processes because of inattention to the environment category in recent years. However, in the organization's missions, they must pay attention to environmental values, set long-term goals from an environmental perspective, and implement programs to train staff and managers to protect the environment.

This study is the first effort to extract the weight or importance of evaluation models written in the gas refinery industries. The results showed that the proposed model of the EPE assessment is relatively close to $99 \%$ and has priority over other models to assess the environmental performance of the gas refinery.

\section{Ethical Considerations}

\section{Compliance with ethical guidelines}

The authors certify that all data collected during the study are as stated in the manuscript. This manuscript is the original work of the authors, and no data from the study have been published elsewhere.

\section{Funding}

This article was extracted from a $\mathrm{PhD}$. dissertation of the first author at the Department of Environment, Faculty of Natural Resources, Bandar Abbas Branch, Islamic Azad University, Bandar Abbas.

\section{Authors' contributions}

All authors were equally contributed in preparing this article.

\section{Conflict of interest}

The authors declared no conflict of interests.

\section{Acknowledgments}

The authors wish to express their gratitude to the SPGC in Bushehr Province, Iran, for their support in this research.

\section{References}

[1] Hassas Yegane Y, Babajani J, Taghi Taghavifard M, Arianpoor A. [Analysis of environmental sustainability performance and its impact on the cost of equity in companies listed in Tehran stock exchange (Persian)]. Valued Behav Account. 2018; 3(5):1-39. [DOI:10.29252/aapc.3.5.1]

[2] Abbas Khan K, Zaman K, Shoukry AM, Sharkawy A, Gani $\mathrm{S}$, Sasmoko, et al. Natural disasters and economic losses: 
Controlling external migration, energy and environmental resources, water demand, and financial development for global prosperity. Environ Sci Pollut Res Int. 2019; 26(14):14287-99. [DOI:10.1007/s11356-019-04755-5] [PMID]

[3] Kasayanond A, Umam R, Jermsittiparsert K. Environmental sustainability and its growth in Malaysia by elaborating the green economy and environmental efficiency. Int J Energy Econ Policy. 2019; 9(5):465-73. [DOI:10.32479/ijeep.8310]

[4] Omidvari M, Ghandehari M. [A pattern of environmental system assessment in urban management by AHP method (Persian)]. J Environ Sci Technol. 2019; 21(7):207-19. [DOI:10.22034/ JEST.2020.690.0]

[5] Hill MK. Understanding environmental pollution.4th ed. Cambridge: Cambridge University Press; 2020. [DOI:10.1017/9781108395021]

[6] Rahmanpour S, Ramezani M. [Investigating the role of environmental education of local communities on environmental performance of citizens of district 5 of Tabriz Municipality (Persian)]. J Soc Stud. 2019; 11(41):151-69. http://jss.iaut.ac.ir/ article_664337.html

[7] Dubey R, Gunasekaran A, Childe SJ, Papadopoulos T, Luo $\mathrm{Z}$, Wamba SF, et al. Can big data and predictive analytics improve social and environmental sustainability? Technol Forecast Soc Change. 2019; 144:534-45. [DOI:10.1016/j.techfore.2017.06.020]

[8] Elmagrhi MH, Ntim CG, Elamer AA, Zhang Q. A study of environmental policies and regulations, governance structures, and environmental performance: The role of female directors. Bus Strategy Environ. 2019; 28(1):206-20. [DOI:10.1002/bse.2250]

[9] Azar A, Bakhtiari H, Mohammadi M. [Evaluating and comparing the organization diagnosis methodologies with fuzzy AHP (Persian)]. Strateg Manag Thought. 2013; 7(2):189-213. [DOI:10.30497/SMT.2013.1706]

[10] Padash A, Nabi Bidhendi G, Hoveidi H, Ardestani M. [Analysis of innovative environmental planning strategy with HSE approach in petrochemical industry (Persian)]. Organ Resour Manag Res. 2016; 6(2):27-47. http://ormr. modares.ac.ir/article-28-6325-en.html

[11] Salehibarmi M, Rezaei AA, Noori Kermani A. [The environmental performance evaluation of tehran municipality based on the green city indicators (Persian)]. Urban Manag Stud. 2018; 10(33):1-15. https://ums.srbiau.ac.ir/article_12673.html?lang=en

[12] Song ML, Fisher R, Wang JL, Cui LB. Environmental performance evaluation with big data: Theories and methods. Ann Oper Res. 2018; 270(1):459-72. [DOI:10.1007/s10479-0162158-8]

[13] Najafzadeh B, Mamipour S. [Measurement of environmental performance of Iranian electric power companies (in the context of contemporaneous and sequential frontiers of slackbased measures and directional distance functions) (Persian)]. J Appl Econ Stud Iran. 2016; 5(19):211-40. [DOI:10.22084/ AES.2016.1604]

[14] Haghgoo S. [Evaluation of environmental performance and mechanisms affecting it according to ISO 14031 (Persian)]. Paper presented at: $3^{\text {rd }}$ Conference on Environmental Planning and Management. 26 November 2013; Tehran, Iran. https:/ / civilica.com/doc/239796/
[15] Guijarro F. A multicriteria model for the assessment of countries' environmental performance. Int J Environ Res Public Health. 2019; 16(16):2868. [DOI:10.3390/ijerph16162868] [PMID] [PMCID]

[16] del Mar Alonso-Almeida M, Fuentes-Frías VG. International quality awards and excellence quality models around the world A multidimensional analysis. Qual Quant. 2012; 46(2):599-626. [DOI:10.1007/s11135-010-9416-7]

[17] Talwar B. Comparative study of framework, criteria and criterion weighting of excellence models. Meas Bus Excell. 2011; 15(1):49-65. [DOI:10.1108/13683041111113240]

[18] Reaño RL. Assessment of environmental impact and energy performance of rice husk utilization in various biohydrogen production pathways. Bioresour Technol. 2020; 299:122590. [DOI:10.1016/j.biortech.2019.122590] [PMID]

[19] Khajavi A. [The role of research and development in wealth production for the world's top oil and gas companies (Persian)] Scie J Oil Gas Explor Prod. 2010; 74:18-20. http://ekteshaf.nioc ir/article-1-682-fa.htm

[20] Ghorbanpour A, Parsa H, Ravan-Bad Y. [Analysis of environmental performance of petrochemical complexes located in Pars special economic zone with a fuzzy mixed approach (Persian)]. Paper presented at: 2nd International Conference on Modern Developments in Management, Economics and Accounting. 10 June 2016; Tehran, Iran. https:/ / civilica.com/doc/782275/

[21] Sepasi S, Hassani H, Salmanian L. [Working capital management, corporate performance and financial constraints: Evidence from Tehran stock exchange (Persian)]. J Asset Manag Financ. 2017; 5(4):99-116. [DOI:20.1001.1.23831170.1396.5.4.8.8]

[22] Sarkheil H, Rahbari S. [Environmental performance assessment and management of the south pars gas complex, comparing refineries: one and 9-10 (Persian)]. J Environ Sci Technol. 2017; [In Press]. https://jest.srbiau.ac.ir/article_10998. html?lang=en

[23] Perotto E, Canziani R, Marchesi R, Butelli P. Environmental performance, indicators and measurement uncertainty in EMS context: A case study. J Clean Prod. 2008; 16(4):517-30. [DOI:10.1016/j.jclepro.2007.01.004]

[24] Dabaghian S, Rezaei Zadeh M, Muhammadi M, Alikhani P. An Analytical Look at Internal Employee Performance Evaluation Software. Paper presented at: 1st Conference on Human's Growth, Development and Health. 17 December 2018; Tehran Iran. https://civilica.com/doc/825419/

[25] Mostofianzadeh MH, Anvari A, Fili A. Presenting a performance evaluation model using balanced scorecard and interpretive structural modeling (case study: Shahr bank). 1st National Conference on Management, Ethics and Business. 2019; Shiraz, Iran. https://civilica.com/doc/918429/

[26] Marvi R. [A study of the financial performance of construction companies (Persian)]. Nowshahr: Islamic Azad University; 2014.

[27] Seyed-Javadin R, Keymasi M. [Service Quality Management (Persian)]. Tehran: Negah-e-Danesh; 2015

[28] Kaplan RS, Norton DP. Putting the balanced scorecard to work [Internet]. 1993 [Updated 1993 September-October] https://hbr.org/1993/09/putting-the-balanced-scorecard-towork

[29] Kasbi HR, Hassani L. An Investigation of the Relationship between Emotional Intelligence and Conflict Management on job performance in Bandar-Abbas shipbuilding. 
Journal of Research in Psychology and Education. 2017; 2(20):157-79. https://www.noormags.ir/view/en/articlepage/80484/134/image

[30] Vafaei F. [Designing a mathematical model to measure the performance of MADM compensation models using Data Envelopment Analysis (DEA) in European Foundation for Quality Management (EFQM) (Persian)]. [PhD. dissertation]. Tehran: University of Tarbiat Modares; 2007.

[31] Eskildsen JK, Dahlgaard JJ. A causal model for employee satisfaction. Total Qual Manag. 2000; 11(8):1081-94. https:// www.researchgate.net/publication/247507202_A_causal_ model_for_employee_satisfaction

[32] Johnson S. EFQM and Balanced Scorecard for improving organizational performance. Inland Revenue. 2003. https:// scholar.google.com/scholar?hl=en\&as_sdt=0\%2C5\&q=EFQ $\mathrm{M}+$ and+Balanced+Scorecard+for+improving+organizationa $1+$ performance.+Inland+Revenue $\% 2 \mathrm{C}+\mathrm{A}+$ Reaserch+Report $\& b \operatorname{tnG}=$

[33] ISO14031. Environmental management: Environmental performance evaluation - guidelines. $2^{\text {nd }} e d$. Geneva: ISO; 2013. https:/ / books.google.com/books?id=5jD2jgEACAAJ\&dq

[34] Mohammadi M, Ghasemi S, Parvaresh H, Dehghani Ghanateghestani M. Presenting an environmental performance evaluation model for gas refineries: A case study in the South pars gas complex, Iran. Environ Health Eng Manag. 2021; 8(2):95-106. [DOI:10.34172/EHEM.2021.13]

[35] Falahati M, Karimi A, Dehdari M, Salehi F. [Health safety, environment performance assessment indicatiors (Persian)] Tehran: Avaye Ghalam Publications; 2019. http://opac.nlai. ir/opac-prod/bibliographic/5804240

[36] Muhammad-Rezaei S. [Introducing a model for evaluating the environmental performance of organizations (Persian)] Paper presented at: $2^{\text {nd }}$ National Conference on Performance Management. 18 May 2005; Tehran, Iran. https://civilica. com/doc/23879/

[37] Farashi A, Zakariyapanah Gashti M, Khorasani N. [The evaluation model for function of municipality's environment in maintaining ISO14001: 2004 standard (case study: 7 region municipal in Tehran) (Persian)]. J Environ Stud. 2010; 36(54):69-76. [DOI:20.1001.1.10258620.1389.36.54.9.4]

[38] Hassani E, Sardoueinasab M, Balavi M, Mashhadi A. [Environmental self-regulation of companies in oil and gas industry (Persian)]. Pvt L. 2021; [In Press]. [DOI:10.22059/ JOLT.2021.305856.1006874]

[39] Smandek B, Barthel A, Winkler J, Ulbig P. Balanced score card implementation for IP rights management in a public research institution. Meas Bus Excell. 2010; 14(4):65-75. [DOI:10.1108/13683041011093767]

[40] Williams R, Bertsch B, van der Wiele A, van Iwaarden J, Dale B. Self-assessment against business excellence models: A critiqueand perspective. Total Qual Manag Bus Excell. 2006; 17(10):1287-300. https://www.researchgate.net/publication/233007562_Self-Assessment_Against_Business_Excellence_Models_A_Critiqueand_Perspective

[41] Azami S, Pourkarimi L, Sadri S. [Total factor $\mathrm{CO}_{2}$ emission performance in Iranian manufacturing industries: Meta-frontier non-radial malmquist index approach (Persian)]. J Econ Model Res. 2018; 8(31):131-63. [DOI:10.29252/jemr.8.31.131] 